Teologia i Moralność, volumen 14(2019), numer 1(25)

doi: $10.14746 /$ tim.2019.25.1.4

ORCID: 0000-0002-9186-8467

JAN ORZESZYNA

Uniwersytet Papieski Jana Pawła II w Krakowie

Wydział Teologiczny

\title{
Teologia moralna wobec wyzwań współczesności
}

Teologia moralna jest dyscypliną teologiczną, która w świetle Bożego objawienia szuka norm dla ludzkiego działania, dzięki czemu może ono być rozumne i wolne. Spełnia ona zatem wymogi ludzkiego rozumu. Jest refleksją, która dotyczy moralności, czyli dobra i zła ludzkich czynów, oraz osoby, która ich dokonuje. W tym sensie jest więc otwarta na wszystkich ludzi oraz na aktualne uwarunkowania ich czynów.

Nie powinno zatem dziwić, że Sobór Watykański II, uwzględniając psychofizyczną i duchową kondycję człowieka, wezwał teologów moralistów, aby, przy zachowaniu metod i wymogów właściwych nauce teologicznej, szukali ,coraz to bardziej odpowiedniego sposobu podawania doktryny ludziom sobie współczesnym; bo czym innym jest sam depozyt wiary, czyli jej prawdy, a czym innym sposób jej wyrażania, przy zachowaniu jednak tego samego sensu i znaczenia" (KDK, nr 62). Tym samym teologowie moraliści zostali zobligowani, aby ,żyjąc w łączności z ludźmi swoich czasów, starali się uchwycić ich sposoby myślenia i odczuwania, znajdujące wyraz w ich kulturze umysłowej" (KDK, nr 62).

W nawiązaniu do tych wskazań warto przyjrzeć się niektórym przejawom współczesnej kultury umysłowej mającej wpływ na rozumienie norm moralnych, aby następnie wskazać, w jakim kierunku winna podążać współczesna teologia moralna. Wcześniej jednak należy się zastanowić, czy należy mówić o rozwoju, czy o zmianie moralnego nauczania. 


\section{Rozwój czy zmiana moralnego nauczania?}

Słyszy się czasem dumne i chwytliwe stwierdzenie mówiące o nowoczesnej moralności, jakby miała ona być wynikiem jakichś nadzwyczajnych rewolucyjnych zmian. Rodzi się więc pytanie, czy współczesne uwarunkowania społeczno-kulturowe na tyle się zmieniły, że nastała konieczność dostosowania do nich chrześcijańskiej moralności.

Nasuwa się pytanie: Czy może się w ogóle dokonywać jakiś rozwój w chrześcijańskiej moralności? Oczywiście, że może, i to bardzo wielki. W przeciwnym razie Kościół nie byłby wierny człowiekowi. Potwierdza to zresztą historia dogmatów i historia teologii moralnej. W nie tak dawnym, kazuistycznym ujęciu teologii moralnej uwagę koncentrowano głównie na analizie czynów moralnych i poprawnym rozwiązywaniu moralnych dylematów. Była to moralność pragmatyczna, mająca na uwadze jedynie działanie, a mało troszcząca się albo wcale nietroszcząca się o ogólne ujęcie systemowe. Być „moralistą” znaczyło być „kazuistą”. Święty Tomasz natomiast twierdził, że przedmiotem moralności winno być stawanie się dobrym poprzez przyswajanie sobie cnoty. Tymczasem kazuistyka usiłowała tylko ustalić, co jest grzechem. Cnotą zajmowano się zaledwie ubocznie (por. Marcol 1998, s. 60). Problem moralnego postępowania ujmowano w kategoriach: „odtąd - dotąd”, nie uwzględniając w pełni problemu wolności człowieka.

Z kolei posoborowa teologia moralna na plan pierwszy wysunęła ideę Bożego powołania i odpowiedzi człowieka na to powołanie. Jednak zagubiono nieco istotny element moralności, jakim jest ocena konkretnych czynów. Tak więc $\mathrm{w}$ historii teologii moralnej następowały i powstają nowe ujęcia nauczania teologii moralnej. Zawsze był to jednak rzeczywisty rozwój moralności, a nie zmiana. O rozwoju mówimy wtedy, gdy coś się zmienia, doskonali, nie przestając być sobą. Zmiana $\mathrm{z}$ kolei ma miejsce wówczas, gdy jedna rzecz przeobraża się $\mathrm{w}$ drugą. Jest zatem rzeczą konieczną, aby $\mathrm{z}$ biegiem czasu, gdy rozwija się wiedza i zmieniają się uwarunkowania kulturowe, rozwijało się również rozumienie norm moralnych, jednakże z zachowaniem tego samego znaczenia i tej samej treści.

Wysuwane pod adresem teologii moralnej coraz to nowe postulaty natury treściowej i metodologicznej podyktowane są niewątpliwie troską o to, by dyscyplinie tej zagwarantować rzeczywiście walor autonomicznej nauki teologicznej o moralności. Stąd też zrozumiałe stają się przeakcentowywania tej dziedziny wiedzy czy to w kierunku jej ubiblijnienia - przez usunięcie na bok refleksji etycznej - czy też w kierunku jedynie analiz filozoficznych, przy obfitym udziale pozateologicznych nauk o człowieku. Można ogólnie powiedzieć, że zasadnicze wysiłki idące w kierunku poszukiwania odnowy teologii moralnej zmierzały z jednej strony do ścisłego jej powiązania $\mathrm{z}$ etyką filozoficz- 
ną, z drugiej zaś - jako dyscypliny teologicznej - z naukami teologicznymi, zwłaszcza z antropologią teologiczną (por. Góralczyk 1992, f. I, s. 57).

\section{Zdaniem Jana Pawła II}

należy poszukiwać i znajdywać coraz właściwsze ujęcia uniwersalnych i trwałych norm moralnych, aby bardziej odpowiadały one różnym kontekstom kulturowym, by zdolne były lepiej wyrażać ich niezmienną aktualność w każdym kontekście historycznym, by pozwalały prawidłowo rozumieć i interpretować zawartą w nich prawdę. Ta prawda prawa moralnego, podobnie jak prawda depozytu wiary, ujawnia się stopniowo w ciągu stuleci: wyrażające ją normy w swej istocie pozostają w mocy, muszą jednak być uściślane i definiowane eodem sensu eademque sententia (w tym samym sensie i w tym samym rozumieniu) w świetle historycznych okoliczności przez Magisterium Kościoła, którego decyzję poprzedza i wspomaga proces ich odczytywania i formułowania, dokonujący się w umysłach wierzących i w ramach refleksji teologicznej (VS, nr 53) ${ }^{1}$.

Również nauczanie moralne Kościoła podlega prawu rozwoju, podobnie jak doktryna wiary. Także do nauczania moralnego odnoszą się następujące słowa Jana XXIII, wypowiedziane z okazji otwarcia Soboru Watykańskiego II (11 października 1962):

Tę pewną i niezmienną doktrynę (tzn. integralną doktrynę chrześcijańską), która musi być wiernie zachowywana, należy pogłębiać i przedstawiać w sposób odpowiadający potrzebom naszych czasów. Czym innym bowiem jest sam depozyt wiary, to znaczy prawdy zawarte $\mathrm{w}$ naszej czcigodnej doktrynie, a czym innym jest forma, w jakiej prawdy te są przedstawiane, pod warunkiem jednak, że zachowują ten sam sens i zasięg (cyt. za VS, nr 53, przyp. 100).

Trzeba zatem wyraźnie powiedzieć, że należy mówić o rozwoju nauczania moralnego Kościoła, a nie o jego nowości czy rewolucyjnych zmianach. Nauczanie moralne Kościoła jest niezmienne, wymaga tylko nowego języka, który trafiłby do współczesnych. Niektórzy wszakże sądzą, że wyjście naprzeciw współczesnemu człowiekowi ma polegać na zmianie, to jest na łagodzeniu wymagań moralnych, jeśli dotychczasowe są trudne do realizacji. Stąd

\footnotetext{
${ }^{1}$ Dla zobrazowania tego procesu św. Wincenty z Lerynu używa następującego przykładu: „Jakkolwiek członki niemowlęcia są małe, ludzi dorosłych zaś duże, to jednak są to zawsze te same członki. Ile ich jest u dzieci, tyle samo u ludzi dorosłych, a jeśli niektóre pojawiają się dopiero w wieku bardziej dojrzałym, to jednak i one znajdują się już wcześniej w zalążku. I tak nic się nie pojawia u starca, czego wcześniej nie było u dziecka. Toteż niewątpliwie jest właściwą i słuszną zasadą postępu, należytą i przedziwną regułą rozwoju, aby późniejszy wiek w bogatych kształtach ujawnił to wszystko, co mądrość Stwórcy umieściła już na samym początku" (Wincenty z Lerynu 1987, s. 283).
} 
w ostatnich latach pojawiły się pewne błędne interpretacje chrześcijańskiej moralności.

\section{Niektóre tendencje współczesnej teologii moralnej}

Jan Paweł II w encyklice Veritatis splendor stwierdza, że po Soborze Watykańskim II pojawiły się pewne interpretacje moralności chrześcijańskiej, których nie sposób pogodzić ze „zdrową nauką" (por. 2 Tm 4,3), gdyż są niezgodne z prawdą objawioną (por. VS, nr 29). Jedną z takich błędnych interpretacji moralności jest przesadne podkreślanie znaczenia wolności, poprzez czynienie z niej absolutu, który ma być źródłem wartości. Konsekwencją takiego rozumienia jest to, że indywidualnemu sumieniu człowieka przyznaje się prerogatywy najwyższej instancji osądu moralnego, która kategorycznie i nieomylnie decyduje o tym, co jest dobre, a co złe. Do tezy o obowiązku kierowania się własnym sumieniem niesłusznie dodaje się tezę, wedle której osąd moralny jest prawdziwy na mocy samego faktu, że pochodzi z sumienia (por. VS, nr 32).

Tym samym zanika wymóg obiektywnej prawdy, co z kolei prowadzi w nieunikniony sposób do zmiany koncepcji sumienia. Według niej, nie przekształca ono obiektywnej normy moralnej w subiektywne przekonanie, ale autonomicznie określa kryteria dobra i zła moralnego. Taka koncepcja sumienia sprzyja etyce indywidualistycznej, według której każdy człowiek ma własną prawdę, różną od prawdy innych. Te różnorodne koncepcje stanowią podłoże nurtów myślowych, według których istnieje antynomia między prawem moralnym a sumieniem (por. VS, nr 32).

Chociaż współcześnie mocno akcentuje się ludzką wolność, to jednak zauważa się paradoksalną sprzeczność, która polega na tym, że zarazem radykalnie się ją kwestionuje. Wynika to z przesadnego zwracania uwagi przez reprezentantów dyscyplin naukowych określanych wspólnym mianem „nauk o człowieku" na uwarunkowania natury psychologicznej i społecznej, które wpływają na sposób, w jaki człowiek korzysta z wolności. Wpływy te, zdaniem niektórych, są tak wielkie, że wręcz negują samą realność ludzkiej wolności (por. VS, nr 33). Konsekwencje takiego sposobu rozumowania widać szczególnie wyraźnie w sytuacjach, kiedy człowieka, który dokonał morderstwa, usprawiedliwia się niepoczytalnością, trudnymi doświadczeniami z okresu dzieciństwa czy też wpływem mediów.

Należy także wspomnieć o pewnych nadużyciach w interpretacji badań naukowych w dziedzinie antropologii. Wskazując na wielką różnorodność tradycji, obyczajów i instytucji, istniejącą w ramach ludzkiej cywilizacji, dochodzi się, jeśli nie zawsze do negacji istnienia uniwersalnych ludzkich 
wartości, to przynajmniej do relatywistycznej koncepcji moralności (por. VS, nr 33).

Niewątpliwy wpływ na rozwój współczesnej teologii moralnej wywiera proces sekularyzacji. Powoduje on przeniesienie akcentu z moralności instytucjonalnej (oddziaływania, a nawet presji instytucji religijnych) na moralność osobistą, związaną z kwestią indywidualnej odpowiedzialności jednostki. Samo przeniesienie akcentu nie jest czymś złym, ale prowadzi ono do zanegowania znaczenia instytucjonalnego wychowania do odpowiedzialności moralnej.

Kolejna kwestia, znajdująca także wyraz w nauczaniu moralnym Jana Pawła II, to wyodrębnianie przez niektórych moralistów tzw. opcji fundamentalnej i wyborów kategorialnych w postępowaniu moralnym. Moraliści ci twierdzą, że jeśli człowiek przez miłość jest fundamentalnie nastawiony na Boga, to różne życiowe tzw. kategorialne wpadki i niedociągnięcia można traktować z przymrużeniem oka. Według tej koncepcji to, co fundamentalne, gwarantuje stan łaski uświęcającej albo jej brak, natomiast to, co kategorialne, jest tylko jakimś brakiem konsekwencji, po prostu wypadkiem przy pracy. Jan Paweł II podkreśla, że każdy zły ludzki czyn jest w gruncie rzeczy zawsze jakimś naruszeniem miłości: Boga, bliźniego i samego siebie, dlatego wprowadzenie podziału na opcję fundamentalną i wybory kategorialne jest niezasadne (por. VS, nr 67).

Przedstawione zjawiska i tendencje stanowią efekt przemian cywilizacyjnych i wyzwań współczesności postulowanych przez wiele nurtów i ideologii, spośród których wymienić należy z pewnością postmodernizm, relatywizm czy permisywizm moralny. Wyzwania te stanowią pewne niebezpieczeństwo, ale $z$ drugiej strony dają też szansę na rozwój i wypracowanie konkretnych rozwiązań, będących odpowiedzią na znaki czasu.

Historia teologii moralnej wskazuje na pewne przemiany zachodzące wewnątrz tej dyscypliny. Przyjmowały one na przestrzeni dziejów różne, niekiedy skrajne, formy, jak chociażby laksyzm czy legalizm. Laksyzm stosuje w postępowaniu moralnym daleko posuniętą dowolność, co owocuje tym, że w identycznych sytuacjach człowiek zachowuje się diametralnie różnie. Z kolei legalizm moralny może prowadzić do faryzeizmu moralnego, potępionego przez Chrystusa, gdyż najpierw wprowadza przepisy, w których litera ważniejsza jest niż duch, a potem używa karkołomnych uzasadnień, pozwalających na ich omijanie.

Godzien uwagi jest wspomniany legalizm, czyli przesadne podporządkowanie moralności prawu, albowiem funkcjonuje on aż po dzień dzisiejszy w świadomości wielu wiernych i w nauczaniu katechetycznym, pomimo reformy, jakiej dokonał Sobór Watykański II. Zauważa to papież Franciszek, czego potwierdzeniem są pewne jego wypowiedzi skierowane zdecydowanie przeciw czysto legalistycznej moralności (Franciszek 2018, s. 42-43; 2017, s. 33-34). 
Począwszy od XVI i XVII wieku wskutek różnych uwarunkowań kształtująca się nauka moralna skupiała się nie na pozytywnym przekazie moralności przez rozwój cnót, lecz na ukazywaniu nakazów i zakazów prawa Bożego i kościelnego. Najważniejsze stało się wyznaczanie granic między tym, co dozwolone, a tym, co zabronione. Pierwszeństwo dano szczegółowym problemom sumienia i kazuistyce w perspektywie indywidualistycznej. Nie byłoby w tym pewnie niczego złego, gdyby nie fakt, że jeden $\mathrm{z}$ aspektów nauczania moralnego w praktyce zawłaszczył całą teologię moralną. W sposób nieunikniony taka moralność uległa interpretacji prawniczej (por. Ciuła 2014, s. 20).

Popularność legalistycznego, kazuistycznego podejścia do życia i moralności niektórzy tłumaczą tym, że dla wielu wierzących ów legalistyczno-kazuistyczny nurt stawał się swoistym bezpiecznym aspektem, który pozwolił uniknąć trudu podejmowania decyzji i brania osobistej odpowiedzialności, ponieważ wszystko wydawało się z góry ustalone i rozstrzygnięte. To fałszywe poczucie bezpieczeństwa prowadziło do minimalizmu i formalizmu moralnego, skupionego jedynie na czysto zewnętrznym przestrzeganiu przykazań, a tym samym stanowiło poważną przeszkodę w kształtowaniu pełnej osobowości moralnej i odnajdywaniu prawdziwego źródła powinności moralnej (por. Nagórny 2001, s. 26-29).

\section{Kryzys w moralności}

Wymienione niektóre błędne interpretacje teologii moralnej w niczym nie podważają nauki moralnej głoszonej przez Kościół. Nie powinny też skłaniać do pesymizmu i obaw, że nauka ta nie będzie respektowana i w konsekwencji dojdzie do totalnej klęski moralności chrześcijańskiej. Każdy bowiem kryzys oznacza nie tylko przesilenie, przełom czy załamanie się dotychczasowej linii rozwoju, ale także, jak podkreśla papież Franciszek, kryje w sobie „dobrą wiadomość, którą trzeba umieć usłyszeć, wytężając słuch serca" (AL, nr 232). Jest zatem wezwaniem do postępu, do poszukiwania nowej drogi rozwoju.

Podobnie jest $\mathrm{z}$ kryzysem w moralności, o którym często się ostatnio mówi. Kryzys ten oznacza, że coraz bardziej dysfunkcjonalne, społecznie i życiowo, a także mało skuteczne stają się tradycyjne systemy etyczne i moralne. Zauważa się wyraźne osłabienie wrażliwości moralnej, swoiste stępienie ludzkich sumień. Innymi słowy, postęp moralny nie nadąża za postępem cywilizacyjnym.

Trzeba wyraźnie podkreślić, że jest to kryzys w moralności, a nie kryzys moralności w ogóle. Nie ulega bowiem zmianom tzw. moralność naturalna, do której należy zdolność rozróżniania dobra od zła, zgodnie z zasadą czyń dobro, a unikaj zła, i wynikających z niej wniosków bezpośrednich, takich jak 
nie zabijaj czy nie kradnij. Jest to zatem głównie kryzys pewnej, nieprzystającej do wymogów współczesności formy moralności.

Można powiedzieć, że jeśli chodzi o współczesny kryzys w moralności, to dostrzegalne jest $\mathrm{w}$ nim nie tyle dezaktualizowanie się czy zużywanie podstawowych wartości i norm moralnych, ile osłabianie się posłuchu dla nich i gotowości do przestrzegania, zwłaszcza w proponowanych pełniejszych i usztywnionych układach, a także w tradycyjnej szacie językowej. Prawdopodobnie jest to kryzys tradycyjnych systemów normatywnych, obyczajowo i społecznie utrwalonych deontologii, różnych kodeksów i zbiorów „praw” etycznych, klasycznych odmian moralistyki i - w znacznej mierze - kryzys tradycyjnego języka (por. Szmyd 2008, s. 5-9 i 26-30).

\section{Słuchanie słowa Bożego podstawą odnowy teologii moralnej}

Co robić, aby wyjść z kryzysu i skutecznie i odpowiedzialnie przekazywać objawioną moralność współczesnym ludziom? Zgodnie z dokumentem Międzynarodowej Komisji Teologicznej, należy przede wszystkim słuchać słowa Bożego (Międzynarodowa Komisja Teologiczna 2005, nr 4-19). „Studium ksiąg świętych” powinno być „duszą świętej teologii” (KO, nr 24). Jest to fundamentalne stwierdzenie Soboru Watykańskiego II w odniesieniu do teologii. Tenże Sobór wzywa moralistów, by szczególną troskę skierowali „ku udoskonaleniu teologii moralnej, której naukowy wykład, karmiony w większej mierze nauką Pisma Świętego, niech ukazuje wzniosłość powołania wiernych w Chrystusie i ich obowiązek przynoszenia owocu w miłości za życie świata" (DFK 16).

Należy podkreślić, że teologia, w ogóle, opiera się na podstawowym akcie słuchania z wiarą objawionego słowa Bożego, czyli samego Chrystusa. Słuchanie słowa Bożego jest definitywną zasadą teologii katolickiej. To właśnie słowo Boże prowadzi do zrozumienia i głoszenia oraz do formowania wspólnoty chrześcijańskiej. Teologia jest bowiem refleksją naukową nad Bożym objawieniem, które Kościół przyjmuje przez wiarę jako powszechną prawdę zbawczą. Należy też pamiętać, że Duch Święty nie tylko natchnął autorów biblijnych, aby znaleźli właściwe słowa świadectwa, ale także pomaga czytającym Biblię w każdym czasie zrozumieć słowo Boże (por. Międzynarodowa Komisja Teologiczna 2012, nr 8).

Papież Benedykt XVI przypomina, że Pismo Święte winno być interpretowane w Kościele (VD, nr 35), ponieważ w wierze katolickiej Pismo Święte, Tradycja i Urząd Nauczycielski Kościoła są nierozdzielnie ze sobą połączone. Papieska Komisja Biblijna wyjaśnia: 
Biblia zawiera bowiem w sobie takie rzeczywistości, które nie dadzą się zamknąć w granicach jedynie naukowej analizy tekstu. Kościół nie uważa bowiem Biblii tylko za zbiór dokumentów historycznych, przedstawiających początki chrześcijaństwa; Biblia jest dla Kościoła słowem Bożym, skierowanym właśnie do niego, do Kościoła i do świata całego w jego dzisiejszej postaci" (Papieska Komisja Biblijna 1994, nr 4).

Nowy Testament jednakże ukazuje, że już od samych początków Kościoła niektórzy głosili heretycką interpretację wspólnej wiary, przeciwną Tradycji apostolskiej. W Pierwszym Liście św. Jana czytamy o odłączeniu od komunii miłości, które jest wskaźnikiem fałszywego nauczania (por. $1 \mathrm{~J}$ 2,18-19). Ponadto, herezja jest nie tylko wypaczeniem Ewangelii, ale szkodzi również samej wspólnocie kościelnej. Herezją nazywa się uporczywe, po przyjęciu chrztu, zaprzeczanie jakiejś prawdzie, w którą należy wierzyć wiarą boską i katolicką, albo uporczywe powątpiewanie o niej (por. KKK, nr 2089). Ten, kto jest winny takiej uporczywości w stosunku do nauczania Kościoła, stawia własny osąd w miejsce posłuszeństwa słowu Bożemu (por. Międzynarodowa Komisja Teologiczna 2012, nr 14).

Można przypuszczać, że jeśli w XX wieku pojawiły się pewne błędne interpretacje moralności chrześcijańskiej, to być może stało się tak w znacznej mierze dlatego, że bardziej zaczęto się wsłuchiwać w głos ludzi niż w głos Boga. Szerzące się idee marksizmu zwróciły uwagę na głos uciemiężonych ludów. Głos wołający o przezwyciężenie jaskrawej niesprawiedliwości stał się dominujący, zwłaszcza w krajach Ameryki Łacińskiej w związku z teorią wyzwolenia. Oczywiście, nie należy ignorować głosu uciemiężonych ludów, trzeba ich słuchać. Jednak nie można zapominać, że źródłem norm moralnych jest Bóg. To nie prawo Boże ma być dopasowywane do słabnącej moralnej kondycji społeczeństwa, ale człowiek ma się podnosić do godności dziecka Bożego. Dzisiaj jednak daje się zauważyć, że dla niektórych moralistów dominujący staje się głos osób w różnoraki sposób pokrzywdzonych przez los, nieradzących sobie w życiu, a nie głos Boga wzywający do respektowania prawdy objawionej.

Przyczyn takiego stanu rzeczy należy upatrywać z pewnością w osłabieniu wiary, zaniku zdrowej pobożności, a nade wszystko pokory. Wsłuchiwanie się w głos Boga wymaga bowiem od moralisty wyciszenia się, pokory, pozycji „na kolanach” przed Bogiem, postawy: chcieć usłyszeć to, co Bóg mówi, a nie potwierdzenia przez Boga tego, co się chce usłyszeć.

Choć wsłuchiwanie się $\mathrm{w}$ głos Boga winno być pierwszorzędne, to nie znaczy, by ignorować głos człowieka². Aby wyjść naprzeciw człowiekowi

\footnotetext{
${ }^{2}$ Należy być otwartym na jego wołanie, ale też należy zadbać o to, by odpowiadać na rzeczywiste potrzeby człowieka, a nie zajmować się zagadnieniami, które ludzi tak naprawdę nie dotyczą. Bywa niekiedy tak, że kaznodzieje mówią o tym, co się im samym podoba i są przekonani, że to
} 
i dobrze go poprowadzić, trzeba nade wszystko słuchać Boga. Trzeba także wsłuchiwać się w głos wiernych, by rozumieć ich problemy. Wierność Bogu i wierność człowiekowi, to podstawowe wyzwanie dla teologii moralnej. Wierność Bogu zakłada wiarę, ponieważ tylko rozum oświecony wiarą jest w stanie odczytać głos Boga. Wiara niezbędna jest moraliście, który odkrywa normy moralne w słowie Bożym, ale potrzebna jest także tym wszystkim, którzy mają je w swoim życiu respektować. Według Katechizmu Kościoła katolickiego „Wiara jest osobowym przylgnięciem całego człowieka do Boga, który się objawia. Obejmuje ona przylgnięcie rozumu i woli do tego, co Bóg objawił o sobie przez swoje czyny i słowa" (KKK, nr 176). Jednak dzisiaj $\mathrm{z}$ wiarą jest pewien problem. Traktowana jest ona jak sprawa prywatna, bez odniesienia do życia. Rozumiana jest często na sposób protestancki, jako osobiste przeświadczenie, że jest się wybranym przez Boga i że będzie się zbawionym niezależnie od swoich uczynków.

\section{Wiara a moralność}

Odnosi się wrażenie, jakby wiara nie miała wpływu na moralność. Jan Paweł II w encyklice Veritatis splendor zauważa, że we współczesnym świecie odrzuca się tradycyjną doktrynę o prawie naturalnym, o powszechności i niezmiennej ważności jej nakazów. Panuje przekonanie, że niektóre elementy nauczania moralnego Kościoła są po prostu nie do przyjęcia. Uważa się, że Magisterium może się wypowiadać w kwestiach moralnych tylko w takim zakresie, by ,zachęcać sumienia" i ,proponować wartości”, z których każdy będzie sam czerpał inspirację dla autonomicznych decyzji i wyborów życiowych (VS, nr 46).

Powstaje pytanie: Czy można być posłusznym Bogu, czyli miłować Boga i bliźniego, nie przestrzegając tych przykazań w każdej sytuacji? Powszechna jest też opinia podająca w wątpliwość istnienie wewnętrznego i nierozerwalnego związku między wiarą a moralnością. Według tej opinii wiara miałaby tylko decydować o przynależności do Kościoła i o jego wewnętrznej jedności, natomiast sposób postępowania człowieka miałby być uzależniony od indywi-

również jest ważne dla słuchaczy kazań. Wielu tym sposobem mówi „,ponad głowami” wiernych, bowiem mówią o problemach, które wiernych nie dotyczą. Dobrym sposobem praktykowanym przez niektórych kaznodziejów, a zwłaszcza rekolekcjonistów jest zwrócenie się do wiernych, by np. przed rekolekcjami zasygnalizowali, o jakich zagadnieniach podczas rekolekcji chcieliby usłyszeć. Oto przykładowo niektóre tematy podawane przez wiernych, na które pragnęli by otrzymać odpowiedź: Mówić o tym, że Bóg kocha ludzi pomimo ich grzechów; rola Eucharystii w budowaniu lepszego życia w rodzinie i społeczeństwie; o odpowiedzialności za zbawienie bliźnich; jak rodzice winni reagować, gdy dzieci nie chodzą do kościoła; jak wzmacniać więzi rodzinne; jak naprawiać małżeńskie relacje; problem wspólnego zamieszkiwania narzeczonych przed ślubem; zagadnienie formacji sumienia, omówić warunki dobrej spowiedzi; dlaczego in vitro jest moralnie niegodziwe. 
dualnego osądu sumienia lub od złożoności uwarunkowań społeczno-kulturowych (VS, nr 4).

To oddzielenie moralności od wiary wpływa na postawy i zachowania chrześcijan, sprawia też, że ich wiara traci żywotność oraz właściwą jej oryginalność jako nowa zasada myślenia i działania w życiu osobistym, rodzinnym i społecznym. Niektórzy wprost wyznają zasadę, że wiara to jedno, a zasady moralne to co innego. Prowadzi to do prywatyzacji zasad moralnych i wiary. Taki sposób myślenia można spotkać u wielu ludzi, zwłaszcza młodych, mówiących: „Bóg jest ok, Kościół w zasadzie też, ale moje życie, moje wybory moralne, moja wiara - to wszystko moja prywatna sprawa”. Przestrzeń, w której się żyje, dzieli się na taką, która należy wyłącznie do człowieka i na należącą wyłącznie do Boga (por. Orzeszyna 2013, s. 74; Błoch 2012, s. 17).

Wbrew temu błędnemu rozumieniu wiary i moralności Jan Paweł II w encyklice Veritatis splendor podkreśla, że wiara zdecydowanie ma wymiar moralny. Jest źródłem zgodnego z nią życiowego zaangażowania i zarazem takiego zaangażowania się domaga. Zobowiązuje do przyjęcia i zachowywania Bożych przykazań (por. VS, nr 89). Na wierze, będącej osobową odpowiedzią człowieka daną objawiającemu się Bogu, winien się wspierać cały gmach życia moralnego. Aby jednak życie moralne było kształtowane przez wiarę, nie wystarczy, że osoba działająca wierzy, ale trzeba, żeby postępowała ona jak wierząca. Ma to miejsce jedynie wtedy, kiedy człowiek świadomie działa pod wpływem wiary. Innymi słowy, czyny chrześcijanina nie mają być tylko z nią zharmonizowane, ale mają wypływać $\mathrm{z}$ dobrowolnie przyjętego daru wiary. Po prostu ma ona być ich źródłem.

Socjologia uczy, że w wymiarze społecznym funkcjonuje tylko to, co jest społecznie uświadomione. Jeśli więc wiara nie jest obecna w życiu społecznym, to de facto nie ma jej w ogóle. Czy zatem problematyka wiary nie powinna dzisiaj stać się podstawowym przedmiotem nauczania moralnego? Przesłanie moralne Kościoła bowiem jest kierowane do ludzi wierzących. Jeśli zatem nie ma żywej wiary, to czy współczesny człowiek jest w stanie przyjąć moralność objawioną? Ponadto wiadomo, że $\mathrm{z}$ wiarą $\mathrm{w}$ Boga wiąże się ściśle pobożność i całe religijne życie człowieka. I tak naprawdę to dopiero te dwie rzeczywistości, wiara i religijność, mogą stanowić podstawę dla opartej na Bożym objawieniu chrześcijańskiej moralności.

\section{Odnowa życia religijnego}

Respektowanie norm moralnych, mających źródło w głoszonym przez Kościół objawieniu Bożym, wymaga radykalizmu i pewnej moralnej doskonałości. Zdaniem Jana Pawła II, aby je respektować, należy spełnić pewne wa- 
runki, które wymienia on w adhortacji Familiaris consortio. Papież wskazuje m.in. na dziecięce zaufanie Bogu, pokorę, częste korzystanie z sakramentów Eucharystii i pojednania oraz na regularną modlitwę (por. FC, nr 33).

Zdaniem Jana Pawła II, do tych warunków należy przede wszystkim głębokie życie religijne. Każdy człowiek rozumny ma prawo pytać: Dlaczego Kościół głosi to, co głosi? Dlaczego mam postępować w taki, a nie inny sposób? Gdy taki człowiek będzie dojrzewał w wierze, jego rozum oświecony wiarą będzie coraz bliższy właściwemu zrozumieniu nauki Kościoła, a zadawane pytania będą służyły szczeremu poszukiwaniu prawdy, a nie szukaniu błędów i wypaczeń. Trzeba przyznać, że oficjalne dokumenty Kościoła bywają z zasady trudne do zrozumienia dla przeciętnego katolika. Trud duszpasterski polega na tym, aby to hermetyczne nauczanie przełożyć na konkrety życia zwykłych ludzi, pokazać, że wymagania służą temu, by wierni mogli doświadczyć w swoim życiu czegoś bardzo pięknego (por. FC, nr 33).

Wiadomo, że wierni bez żywej wiary w miłość Boga do nich nie będą umieli podjąć niektórych decyzji porządkujących ich życie według wskazań Kościoła. To bowiem miłość Boga rozlana w sercu chrześcijanina jest wewnętrznym nośnikiem uzdolniającym do zmiany postaw i zachowań. Ważną rolę odgrywa zatem budzenie u wiernych przekonania, że z pomocą łaski Bożej, nawet wbrew doświadczanej ludzkiej słabości, możliwe jest zachowanie woli Boga w chrześcijańskim życiu. Innymi słowy, warunkiem zrozumienia i przyjęcia nauczania moralnego Kościoła jest wiara i żywa realna więź z Bogiem³.

Drugim warunkiem koniecznym do zaakceptowania norm moralnych głoszonych przez Kościół jest poznanie niezbędnych w danej dziedzinie naturalnych praw. Wielką przeszkodą w zaakceptowaniu nauki Kościoła jest dla dzisiejszych katolików słaba znajomość dokumentów Kościoła i podawanej przez nie rozumowej argumentacji, odwołującej się do argumentów z dziedzin humanistycznych. W konsekwencji brak tej wiedzy może prowadzić do negowania norm moralnych, a tym samym do braku zaufania do nauki Kościoła (por. FC, nr 33).

Wymienione najważniejsze warunki konieczne do zaakceptowania nauki moralnej głoszonej przez Kościół pokazują, że w człowieku musi się dokonać jakaś przemiana, jakieś przewartościowanie, które umożliwi zachowanie

\footnotetext{
3 „Bardzo często, gdy uda się porozmawiać z małżonkami stosującymi np. antykoncepcję, okazuje się, że swojego życia seksualnego nie przeżywają tak beztrosko, bezproblemowo i szczęśliwie, jakby się wydawało. Jest w nich wiele cierpienia, poczucia niekochania, braku zaufania. Gdzieś na dnie duszy tli się świadomość zła. Rozmowa z duszpasterzem może pokazać małżonkom, że chrześcijanie są powołani do tego, aby odkryć obecność samego Boga także w niepowtarzalnej więzi, która jednoczy tylko małżonków. Istnieje bowiem świat głębszych przeżyć, wykraczających poza sferę zmysłowych i psychicznych odczuć. To tajemnica nieprzenikniona dla ludzi oddalonych od Boga" (Orzeszyna 2010, s. 234).
} 
nauki Kościoła. Uświadamiają również, że wielu katolików nie jest jeszcze dojrzałych $\mathrm{w}$ wierze $\mathrm{i}$ w konsekwencji nie widzi dobra, jakie płynie z życia zgodnego z zasadami moralnymi, nie dostrzega piękna takiego życia, a wręcz, nie rozumiejąc sensu wymagań, odczuwa je jako przeszkodę na drodze do szczęścia.

Co zatem czynić, aby to zmienić? Jest to niewątpliwie poważne wyzwanie stojące przed teologią moralną, a właściwie przed całym Kościołem. Nie chodzi bowiem tylko o samo głoszenie nauki moralnej, ale nade wszystko o przygotowanie ludzkich serc na otwarcie się na działanie Bożej łaski. Warto zatem zwrócić uwagę na pewne wyzwania współczesności, które w jakimś stopniu mogą wytyczać kierunek dyskusji i poszukiwań teologii moralnej w najbliższym czasie.

\section{Niektóre wyzwania wspólczesności}

Teologowie moraliści, zgodnie ze swoją funkcją w Kościele, którą jest zdobywanie, w łączności z Magisterium, coraz głębszego rozumienia słowa Bożego zawartego w natchnionym Piśmie Świętym i przekazanego przez żywą Tradycję Kościoła, winni podejmować tematy, które mogą stać się niebawem aktualne (por. VS, nr 109). Zdaniem Jana Pawła II, ich posługa ma pierwszorzędne znaczenie nie tylko dla życia i misji Kościoła, ale także dla społeczeństwa i jego kultury. Zachowując ścisłą i niezbędną więź z teologią biblijną i dogmatyczną, powinni podkreślać w naukowej refleksji dynamiczny aspekt moralności, to znaczy poświęcić szczególną uwagę odpowiedzi, jakiej na Boże wezwanie winien udzielić człowiek w procesie swego wzrastania w miłości w łonie zbawczej wspólnoty, tj. Kościoła (por. VS, nr 111).

Teolog moralista winien, niezależnie od pojawiających się trudności, głosić moralność ludzkiego postępowania wynikającą z objawienia Bożego. Skoro pojawiają się trudności i zagrożenia, nie należy ich pomijać, ale próbować znaleźć ich przyczyny i uwarunkowania. Byłoby błędem ignorować je i tylko potępiać. Bez wątpienia, nowych przemyśleń, gdy chodzi o rozwój moralności, wymaga aktualnie moralność społeczna, zwłaszcza zagadnienie grzechu społecznego, wynikającego z patogennych struktur społecznych, przy zachowaniu zasady odpowiedzialności indywidualnej za grzech. W życiu społecznym chodzi także o zgłębienie i dopracowanie takich zagadnień, jak moralność polityczna, moralność gospodarcza, solidarność globalizacyjna czy wrażliwość ekologiczna.

W kontekście współczesnych wyzwań warto zwrócić uwagę na rozwój nauk o człowieku oraz ich wkład w teologię moralną. Należy jednak wyraźnie odróżniać chrześcijańską moralność od lansowanej często moralności laickiej. 
Ta pierwsza ma wymiar responsoryczny, czyli jest odpowiedzią na wezwanie miłującego Boga, a nie respektowaniem bezdusznych nakazów i zakazów. Z kolei moralność laicka, której źródłem jest często scjentyzm, fizycyzm, naturalizm, eklektyzm, pragmatyzm, nihilizm czy egzystencjalizm ateistyczny, jest moralnością eudajmonistyczną. Jej celem staje się uzyskanie satysfakcji, zadowolenia, przyjemności. Jest to często moralność liberalistyczna i hedonistyczna.

Podstawą zdrowej moralności jest właściwa antropologia teologiczna, bo ukazuje człowieka w pełnym wymiarze jego egzystencji. Taka moralność ma charakter personalistyczny (gwarantuje rozwój osobowy) a równocześnie dialogiczny (kształtuje poprawne relacje z Bogiem i ludźmi).

Szczególnej uwagi moralisty wymagają zagadnienia z zakresu bioetyki. Pojawiające się nowe odkrycia, badania, eksperymenty medyczne wymagają nieustannej troski o respektowanie prawa człowieka do życia i poszanowania jego godności.

Istotne jest także zwrócenie uwagi na język, jakim posługuje się teologia moralna. Wymaga on wciąż odnowy, by nowym językiem głosić światu starą, niezmienną prawdę. Chodzi o to, by mówić o rzeczywistości tak, żeby nie utracić teologiczno-religijnej istoty, by nie zamazywać prawdy. Bardzo często publicystyka w tej dziedzinie naraża teologię moralną na uproszczenia. Musi ona być zorientowana kerygmatycznie na rzeczywistość ludzką. Nie można moralizować. Trzeba przekazywać Bożą prawdę. Kerygmat tym różni się od mentorstwa (moralizowania), że nie wypływa z poczucia dominacji czy duchowej wyższości, ale jest partnerskim świadectwem żywej wiary, w której przejawia się moc samego Boga. Przepowiadanie moralności objawionej przez Chrystusa pojmowane jest niekiedy jako wojowanie o prawo Boże w tym świecie, co poniekąd w jakimś wymiarze jest słusznym działaniem. Inni zaś widzą powodzenie ewangelizacji w sile przedstawianych argumentów, bez wątpienia są one ważne i potrzebne. Wydaje się jednak, że najsilniejszym orężem w głoszeniu moralności chrześcijańskiej jest dawanie świadectwa. Można powiedzieć, że to, co może przekonać świat do powrotu do Boga, to świadectwo szczęśliwego życia chrześcijan, ludzi, którzy swoim przykładem pokazują, że kiedy człowiek jest z Bogiem, to wszystko da się zrobić, że można być osobą dobrą, kochającą i spełnioną.

Dającą wiele do myślenia kwestią jest brak spójności między głoszonymi w Kościele zasadami moralnymi a życiem niektórych wiernych. Odnosi się to zwłaszcza do dokonywanych przez nich moralnych rozstrzygnięć. Pokazały to choćby ostatnie wybory samorządowe w Polsce (2018), podczas których część wyborców głosowała na kandydata na prezydenta miasta aktualnie siedzącego w więzieniu. Podobnie jest z przyzwoleniem na aborcję. Jak wykazują badania statystyczne, tylko 24\% katolików w Polsce jest za całkowitym zakazem 
aborcji. Pozostali, w jakiś zadziwiający sposób, godzą przyzwolenie na aborcję ze swoją pobożnością. Takie zjawiska skłaniają nie tylko do poszukiwania przyczyn takiego stanu rzeczy, ale nade wszystko do zastanowienia się, czy język i argumentacja, jakimi posługuje się teologia moralna, są wystarczająco zrozumiałe i przekonywające.

Bez wątpienia ważnym wyzwaniem dla teologii moralnej dzisiaj jest przypomnienie nauki o sakramentach. Widoczny jest rodzaj totalnego zagubienia i niezrozumienia, czym one są. Wielu pojmuje je tylko jako dar Boży, jako nagrodę za dobre postępowanie, a nie dostrzega ich moralnego wymiaru, czyli nie postrzega ich jako daru zobowiązującego. Wielu też w praktyce duszpasterskiej bywa przygotowywanych tylko do przyjęcia danego sakramentu, a już nie do życia po jego przyjęciu. Nic zatem dziwnego, że młodzież przygotowywana tylko do przyjęcia sakramentu bierzmowania, a nie do zadań, jakie stawia on przed nią, traktuje go jako „sakrament pożegnania” z Kościołem.

Trzeba sobie uświadomić, że przecież sakrament to działanie Chrystusa w Kościele, a nie duszpasterska akcja. Każdy sakrament stawia przed przyjmującym go powinności moralne dotyczące jego życia osobistego, eklezjalnego i społecznego. Bywa też, że sakramenty traktuje się magicznie, akcentując przesadnie ich drugorzędne znaczenie, jak np. uzdrowienie fizyczne w związku z namaszczeniem chorych. Ponadto Kościół niezmiennie podkreśla, że tzw. sakramenty żywych należy przyjmować w stanie łaski uświęcającej.

Przypomnienia moralnej nauki Kościoła wymaga także prawda o grzechu. Obok zaniku poczucia grzechu pojawiają się także błędne jego interpretacje, sięgające korzeniami do obcych chrześcijaństwu wierzeń, np. reinkarnacji czy demonologii. Przykładem takich wypaczeń jest teoria o tzw. grzechu pokoleniowym, a w konsekwencji praktyka tzw. spowiedzi furtkowej.

Od początku istnienia Kościoła chrześcijanie byli prześladowani i zmuszani, by płacić życiem za swoją wiarę. Historia Kościoła naznaczona jest krwią męczenników. Na przestrzeni stuleci męczeństwo rozumiane było jako najbardziej radykalna możliwość naśladowania Chrystusa. Stało się wręcz ideałem i wzorem świętości i chrześcijańskiego męstwa. W tym kontekście można zrozumieć tęsknotę prześladowanych chrześcijan za cierpieniem i śmiercią z powodu swojej wiary. Jak postępować we wrogim sobie środowisku i jaką postawę przyjąć? Odpowiedź jest jasna: trzeba być wiernym Bogu, nawet aż po męczeństwo. Wiadomo, że wiek XXI jest czasem prześladowania chrześcijan. Jak podają statystyki, co 5 minut ginie jeden człowiek. Wszystko wskazuje na to, że temat gotowości na oddanie życia za wiarę winien stać się przedmiotem moralnego nauczania. Należy poważnie się zastanowić, czy wzorem ojców Kościoła nie należałoby w teologii moralnej i w teologii duchowości podejmować problematyki męczeństwa, tłumacząc, że naśladowanie Chrystusa osiąga najdoskonalszy wyraz właśnie w męczeństwie. O tym, że jest to temat 
aktualny, przekonują nas ostatnie wydarzenia, które mają miejsce w Europie i w naszej Ojczyźnie: publiczne znieważanie wizerunku Matki Bożej czy też wyszydzanie Kościoła i ludzi do niego należących.

Jeszcze jeden temat zasługuje na podjęcie przez moralistów. Wiąże się on $\mathrm{z}$ rozpowszechniającą się praktyką kremacji ludzkich zwłok, a wraz z nią pogrzebów z urną, zamiast z trumną. Zmienia się dość widocznie mentalność w zakresie szacunku dla ludzkiego ciała po śmierci. Może to skutkować w niedalekiej przyszłości zanikaniem tradycyjnych cmentarzy, a co za tym idzie, zmianą rozumienia ludzkiej śmierci i, być może, zanikiem praktyki modlitwy za zmarłych. Już daje się zauważyć, że w niektórych krajach z powodu kremacji zwłok zanika w ogóle zwyczaj grzebania zmarłych i troski o ich grób. Znikają cmentarze. Jest to temat godny przemyślenia i podjęcia z powodu szacunku dla zmarłych i troski o ich zbawienie.

Głębokiej refleksji teologiczno-moralnej domaga się także kwestia utraty relacji społecznych. Zanikają bowiem naturalne więzi, zarówno w małżeństwie, w rodzinie, jak i we wspólnocie narodowej, ojczyźnianej i państwowej. $\mathrm{W}$ ich miejsce pojawiają się jakieś nowe więzi, np. międzynarodowe, które tak naprawdę niczego nie wnoszą do międzyludzkich relacji. Jest to również widoczne we wspólnotach parafialnych, w których ludzie tracą naturalny związek ze swoją parafią na rzecz tzw. churchingu (czyli uczęszczania na mszę świętą do różnych kościołów) czy bliżej nieokreślonych wspólnot kościelnych.

Znaczący wpływ na to ma, bez wątpienia, rozwój Internetu i telefonii komórkowej, które poważnie niszczą naturalną komunikację międzyludzką. Obecnie ludzie coraz rzadziej rozmawiają ze sobą „w cztery oczy”, zarówno w swoich rodzinach, szkołach, miejscu pracy czy też w wolnym czasie spotykając się towarzysko. Jest to bez wątpienia bardzo ważny problem wymagający natychmiastowych działań i podjęcia skutecznych rozwiązań, by przeciwdziałać tym katastrofalnym w skutkach zagrożeniom.

Trudno w krótkim artykule odnieść się do wszystkich współczesnych wyzwań moralnych, ale nie można nie zauważyć lekceważenia regulacji cywilno-kościelnych związków małżeńskich. Niestety dzieje się to często przy aprobacie wierzących rodziców i krewnych. Taka postawa rzutuje bardzo negatywnie na wychowanie przyszłych pokoleń. Słabe rodziny, to słabe społeczeństwa, a w konsekwencji słaby staje się Kościół.

Wielką bolączką jest także dzisiaj brak ciągłości nauczania i jednomyślności niektórych duchownych, wypowiadających się publicznie w kwestii moralnego nauczania Kościoła. Pojawiają się bowiem tendencje do podważania dotychczasowego porządku moralnego. Wielu współczesnych chrześcijan, zwłaszcza młodych, powołuje się na tego typu wypowiedzi, bo są im na rękę, bo im pasują do własnej sytuacji życiowej, bo wreszcie, jest im tak wygodniej. Czasem słyszy się stwierdzenia, że ten ksiądz jest nowoczesny, modny, bo po- 
wiedział coś, co niektórym się podoba. Każda osoba duchowna zabierająca głos powinna zdawać sobie sprawę z tego, co i do kogo mówi.

Należy więc podkreślić, że teologia moralna jest dyscypliną teologiczną, która zajmuje się moralnością czynów ludzkich w świetle objawienia Bożego. Do jej uprawiania potrzebny jest rozum kierowany przez wiarę, co oznacza, że poza ściśle teologiczną argumentacją posługuje się także argumentami rozumowymi (ex ratione). Nie można wszakże wykładu o moralności ograniczać tylko do wyłożenia racji rozumowych. By odczytać Boże wezwanie, niezbędna jest głęboka wiara i żywa, realna więź z Bogiem. Głoszenie nauki moralnej winno iść $\mathrm{w}$ parze $\mathrm{z}$ gorliwością duszpasterską, która jednoczy wiernych z Bogiem i buduje realne wspólnoty ludzi żyjących na serio Ewangelią.

Teologia moralna, będąc nauką teologiczną, formułuje zasady postępowania dotyczące różnych dziedzin ludzkiego życia i jest jednocześnie otwarta na aktualne uwarunkowania ludzkich czynów. Wychodzi naprzeciw wyzwaniom, jakie niesie ze sobą postęp naukowy, techniczny i cywilizacyjny. Świadczą o tym publikowane monografie, artykuły i organizowane sympozja naukowe, na których podejmowane są aktualne zagadnienia moralne. Moraliści są świadomi przeciwności i zagrożeń, które utrudniają głoszenie moralności objawionej we współczesnym świecie.

Dziś w epoce postmodernizmu dominuje tendencja do sprowadzania wszelkiego sądu do indywidualnej oceny, do przedkładania jej ponad obiektywną prawdę. To skutkuje niekiedy odrywaniem moralnych rozstrzygnięć od doktrynalnych fundamentów Kościoła i zbytnim skupianiem się nad skomplikowaną etycznie sytuacją człowieka.

Teologia moralna stanowi taką dziedzinę wiedzy, która jakby z natury swej domaga się ciągłej odnowy i nowej, pogłębionej refleksji nad moralnymi zagadnieniami życia człowieka. Tak zresztą było w historii tej dyscypliny i tak dzieje się dzisiaj.

MORAL THEOLOGY IN THE FACE OF CONTEMPORARY CHALLENGES

\section{SUMMARY}

Moral theology is a theological discipline which deals with the morality of human acts in the light of the God's Revelation. It is for planting to need a mind directed by comrades what is marking, that apart from argumentation closely theological, it is us- 
ing also rational arguments. Moral theology is a theological science; it is formulating rules of conduct concerning different fields of the human life and at the same time, it opens to current conditioning of human acts. It is trying to meet challenges with itself scientific, technical and of civilization progress that is carrying of them.

Today in the age of the postmodernism a tendency of importing all court for the individual evaluation, for submitting to it over the objective truth is dominating. It results sometimes in tearing away moral decisions from doctrinal foundations of the Church and excessive concentrating oneself above the complicated ethically situation of the man. Moral theology constitutes such field of knowledge, which kind of one's is demanding the continuous revival and new, deepened reflection over moral issues of the life of the man. This way as a matter of fact it was in the history of this discipline still is happening today.

Keywords: moral theology; crisis in the morality; faith; Bible; contemporary challenges

Słowa kluczowe: teologia moralna; kryzys w moralności; wiara; Słowo Boże; wyzwania współczesności

\section{BIBLIOGRAFIA}

Benedykt XVI (2010), Adhortacja apostolska o Stowie Bożym w życiu i misji Kościoła „Verbum Domini" (30.09.2010), Kraków.

Benedykt XVI (2019), List o przyczynach kryzysu Kościoła, Kraków.

Błoch G. (2012), Wiara - to sprawa prywatna czy publiczna?, „Franciszkański Świat” nr 2 (72), s. $17-24$.

Ciuła G. (2014), Uwarunkowania czynu ludzkiego. Studium teologicznomoralne na podstawie polskiej posoborowej literatury teologicznej i pozateologicznej, Katowice.

Franciszek (2016), Adhortacja apostolska o mitości w rodzinie „,Amoris laetitia” (19.03.2016), Kraków.

Franciszek (2017), Prawdziwy chrześcijanin nie boi się ryzyka. Audiencja generalna (11.10.2017), „L'Osservatore Romano” 38 nr 11 (397), s. 33-34.

Franciszek (2018), Nie niewolnicy, lecz dzieci. Audiencja generalna (20.06.2018), „L'Osservatore Romano" $39 \mathrm{nr} 7$ (404), s. 42-43.

Góralczyk P. (1992), Gtówne nurty teologii moralnej po Vaticanum II, „Collectanea Theologica” 62, f. I, s. 57-69.

Jan Paweł II (1998), Adhortacja apostolska o zadaniach rodziny w świecie wspótczesnym „, Familiaris consortio" (22.11.1981), Wrocław.

Jan Paweł II (1998), Encyklika o niektórych podstawowych problemach nauczania moralnego Kościoła "Veritatis splendor" (06.08.1993), Wrocław.

Katechizm Kościoła katolickiego (2002), Poznań.

Marcol A. (1998), Korzenie soborowej odnowy teologii moralnej, w: Teologia moralna u kresu II tysiąclecia, red. J. Nagórny, K. Jeżyna, Lublin, s. 59-73.

Międzynarodowa Komisja Teologiczna (2012), Teologia dzisiaj. Perspektywy, zasady i kryteria (29.11.2011), Kraków. 
Nagórny J. (2001), Kościót nakazów i zakazów? Wspótczesne zakwestionowanie „moralności przykazań”, w: Przykazania kościelne dzisiaj. Przesianie moralne Kościoła, red. J. Nagórny, J. Gocko, Lublin, s. 23-60.

Orzeszyna J. (2011), Spowiednik wobec antykoncepcji. W 40. rocznice opublikowania encykliki Pawta VI „Humanae vitae”, „Family Forum” t. 1, s. 227-238.

Orzeszyna J. (2013), Czy wiara decyduje o normach moralnych?, „Polonia Sacra” 17, nr 2 (33), s. $71-83$.

Papieska Komisja Biblijna (1994), Interpretacja Pisma Świętego w Kościele (23.04.1993), Poznań.

Sobór Watykański II, Konstytucja dogmatyczna o objawieniu Bożym „Dei verbum”, w: Sobór Watykański II (2002), Konstytucje, dekrety, deklaracje, Poznań, s. 350-203.

Szmyd J. (2008), Moralność w ponowoczesnym świecie - kryzys i nadzieja, „Res Humana” nr 2, s. 5-30.

Wincenty z Lerynu (1987), Pismo napominające, w: Liturgia godzin, t. IV, Poznań, s. 283-284.

Jan Orzeszyna - ks. prof. zw. dr hab. teologii (teologia moralna), ur. 1954 r. w Wieluniu. Dyrektor Instytutu Teologii Moralnej i kierownik Katedry Teologii Moralnej Szczegółowej na Wydziale Teologicznym Uniwersytetu Papieskiego Jana Pawła II w Krakowie. Członek Stowarzyszenia Teologów Moralistów i Polskiego Towarzystwa Teologicznego. Redaktor naczelny „Sosnowieckich Studiów Teologicznych". 